\title{
Wrongful Convictions and the Culture of Denial
}

\begin{abstract}
On the surface, it appears the United States has a more serious problem with wrongful convictions than Japan, for it has uncovered many more cases of this kind. Yet this gap is probably more apparent than real, for Japan does a poor job of discovering wrongful convictions. To reduce the problem of wrongful convictions in Japanese criminal justice and capital punishment, reformers must make structural reforms, but they must also confront a "culture of denial" (bitei no bunka) that makes it difficult to acknowledge mistakes.
\end{abstract}

Keywords Hakamada Iwao - Wrongful conviction •

Miscarriage of justice $\cdot$ Structural reform $\cdot$ Culture of denial

Hakamada Iwao was sentenced to death in 1968 for the murder of four people. He was released in 2014 because of evidence of his innocence. At the time of his arrest he was a young man. At the time of his release he was 78 years old-diabetic, deluded about his identity, and dimly aware of his own situation. In the five years since he was released, prosecutors have continued to claim that Hakamada is guilty, but as of this writing he remains free, living with his sister in the city of Hamamatsu, struggling to recover his health, and-as a matter of law-still a convicted killer under sentence of death. Time will tell whether Hakamada

(C) The Author(s) 2020

D. T. Johnson, The Culture of Capital Punishment in Japan, Palgrave Advances in Criminology and Criminal Justice in Asia, https://doi.org/10.1007/978-3-030-32086-7_4 
is formally acquitted at a retrial (which may or may not occur), but the three judges on the Shizuoka District Court who ordered his release left little doubt about their view:

In addition to approving a retrial for the defendant, it is natural to suspend the execution of his death sentence. Moreover, based on this court's discretion, we conclude that it is also appropriate to suspend the execution of the defendant's confinement. This defendant has been convicted and incarcerated for an extremely long period of time under the threat of capital punishment based on important evidence that may well have been planted by the investigating authorities. At present, when the high probability of the defendant's innocence has been made clear, detaining him any longer would violate justice to an intolerable extent. ${ }^{1}$

I believe that Hakamada is innocent and that his confinement for almost half a century is an abomination of justice. I also believe that his case is not an isolated accident. ${ }^{2}$ Wrongful convictions result from human and systemic errors that recur on a regular basis. ${ }^{3}$ Hakamada's half-century nightmare resulted from the interaction of several such errors:

- Hakamada falsely confessed to crimes he did not commit. His admissions of guilt were coerced through interrogation practices that lasted more than $\mathbf{2 5 0}$ hours and that broke his will to resist.

- Japanese police apparently planted evidence-clothes in a miso tank near the scene of the crime-in order to frame Hakamada.

- Japanese prosecutors concealed from the defense more than 100 photographs and statements which might have cleared Hakamada decades before they finally acknowledged the existence of this critical evidence.

- Japanese media coverage of the four murders put pressure on police, prosecutors, and courts to produce a conviction. It also contributed to the "tunnel vision" and "confirmation bias" that afflicted legal officials in this case.

${ }^{1}$ David T. Johnson, "An Innocent Man: Hakamada Iwao and the Problem of Wrongful Convictions in Japan", The Asia-Pacific Journal/Japan Focus, Vol. 13 (2015), pp. 1-38.

${ }^{2}$ David T. Johnson, "Wrongful Convictions and the Culture of Denial in Japanese Criminal Justice", The Asia-Pacific Journal/Japan Focus, Vol. 13 (2015), pp. 1-10.

${ }^{3}$ Dan Simon, In Doubt: The Psychology of the Criminal Justice Process (Harvard University Press, 2012). 
- Hakamada's trial failed to ascertain the accuracy of the evidence produced by police and prosecutors, and his defense lawyers contributed to this failure. Criminal trials provide a number of mechanisms that are supposed to safeguard the accuracy of verdicts, including the presumption of innocence, a burden of proof "beyond a reasonable doubt," vigorous cross-examination, and assurances that the adjudicators will be impartial and objective. All of these safeguards miscarried in Hakamada's case.

- For decades, Japan's appellate courts failed to acknowledge problems in Hakamada's case. In effect, they repeatedly ratified the foregoing errors while Hakamada lost his mind on death row.

A criminal case can go wrong in two main ways. A person who committed a crime may escape punishment, or a person may be convicted and punished for a crime that he or she did not commit. Every criminal justice system makes mistakes of both kinds, and most cultures and criminal justice professionals believe that the worst mistake is the false conviction of people who are actually innocent. As British jurist William Blackstone observed in the eighteenth century, "it is better that ten guilty persons escape than that one innocent suffer." An aversion to convicting the innocent is also well established in Japanese legal culture. Indeed, in Japan, even people who are arrested but not convicted are often deemed to be victims of a "miscarriage of justice" (enzai). This kind of criticism is seldom heard in the United States, where it is widely accepted that some people who get arrested will not be convicted. This difference suggests that in some respects Japanese people may be more sensitive than Americans to criminal injustice.

The problem of wrongful conviction in Japan cannot be understood without considering how it compares with other countries. Here as in many areas of social research, to know only one country is to know no country well. Comparison with the United States is especially instructive because there have been many studies of wrongful conviction there and because the United States and Japan are both developed democracies that retain capital punishment and continue to carry out executions on a regular basis. On the surface, the United States seems to have a more serious problem with wrongful convictions than Japan, for it has uncovered many more cases of this kind. But I believe this gap is more apparent than real, for Japan does a deplorable job of discovering wrongful convictions. To reduce the problem of wrongful convictions in Japanese criminal 
justice, reformers must confront a "culture of denial" (bitei no bunka) that makes it difficult for police, prosecutors, and judges to acknowledge their mistakes and that makes the public and the media complicit in their own dimsightedness. ${ }^{4}$

\section{Wrongful Convictions in America and Europe}

The United States has been the subject of more wrongful conviction research than any country in the world. ${ }^{5}$ The results are troubling. From 1989 to 2017 , more than 2100 persons were wrongfully convicted and subsequently released from prison because of evidence of their innocence. ${ }^{6}$ That is 6 exonerations per month for 29 years ( 1 every 5 days). Forty-seven percent of these victims of wrongful conviction were AfricanAmerican even though African-Americans make up only 13 percent of the U.S. population. Victims of wrongful conviction spent an average of 9 years in prison before being released, and many spent two or three times that long. About three-quarters were wrongfully convicted of homicide or sexual assault - crimes which tend to leave physical evidence behind that later can be tested, and crimes which attract more media attention than most criminal cases do. Less than one-quarter of these victims were exonerated based on DNA evidence, partly because biological evidence (saliva, semen, blood, and the like) is available in only 10-15 percent of serious felony cases. The leading causes of wrongful

\footnotetext{
${ }^{4}$ There are several good documentaries about wrongful convictions in Japan. One is about Hakamada, directed by Kim Sung-woong: "Yume no Ma no Yo no Naka" (Kimoon Film, 2016). See also Kim's "Sayama: Mienai Tejo o Hazusu made" (2013), about a burakumin man named Ishikawa Kazuo, who was released in 1994 after serving 31 years in prison, and who has been seeking a retrial ever since his conviction for the kidnapping and murder of a 16-year-old girl in 1963; and "Gokutomo" (2018), about friendships between five men, all of whom were convicted of murder: Hakamada Iwao (released from death row in 2014), Ishikawa Kazuo (released on parole in 1994), Sugaya Toshikazu (acquitted at retrial in 2009), Sakurai Shoji (acquitted at retrial in 2011), and Sugiyama Takao (acquitted at retrial in 2011).

${ }^{5}$ One exemplary work of scholarship on wrongful convictions in America is Mark Godsey, Blind Justice: A Former Prosecutor Exposes the Psychology and Politics of Wrongful Convictions (University of California Press, 2017). Another is Brandon L. Garrett, Convicting the Innocent: Where Criminal Prosecutions Go Wrong (Harvard University Press, 2011).

${ }^{6}$ The National Registry of Exonerations, at https://www.law.umich.edu/special/exoneration/Pages/about.aspx.
} 
conviction in these cases were perjury and false accusation, official misconduct, mistaken witness testimony, false or misleading forensic evidence, and false confessions. All of these causes were operative in the wrongful conviction of Hakamada Iwao, and they have shipwrecked justice in other Japanese cases too.

All wrongful convictions are tragic, but the most worrisome are those that result in a mistaken sentence of death. From 1973 to 2018, 164 persons in 28 American states were released from death row because of evidence of their innocence. ${ }^{7}$ That is an average of 3.6 death row exonerations per year for 46 years. More than half of these exonerations (84) were of black men, and more than half (83) occurred in just five states: Florida (28), Illinois (21), Texas (13), Louisiana (11), and Oklahoma (10). Many analysts believe that some wrongly condemned persons have been executed. For example, Carlos DeLuna, a poor Hispanic man with childlike intelligence, was executed in Texas in 1989 based on one, nighttime, cross-ethnic eyewitness identification with no corroborating forensic evidence. ${ }^{8}$ There is a growing list of executed persons whose guilt has been called into serious doubt following post-execution investigations. America's wrongful executions may also include Ruben Cantu (executed in Texas in 1993), Larry Griffin (Missouri, 1995), David Spence (Texas, 1997), Claude Jones (Texas, 2000), and Cameron Todd Willingham (Texas, 2004). In 2015, the U.S. Justice Department and the FBI formally acknowledged that nearly every examiner in an FBI forensic squad overstated forensic hair matches for two decades before the year 2000. Of 28 forensic examiners who testified to hair matches in a total of 268 trials, 26 were found to have overstated the evidence, and 95 percent of the overstatements favored the prosecution. Defendants were sentenced to death in 12 percent of those trials.

While the foregoing figures are troubling, the true scale of America's wrongful conviction problem cannot be known because some wrongly convicted persons are never discovered. Educated estimates of the percentage of criminal cases resulting in wrongful conviction have been made, and they range from 3 to 5 percent in capital homicide cases, and

\footnotetext{
${ }^{7}$ Death Penalty Information Center, at https://deathpenaltyinfo.org/innocence-anddeath-penalty.

${ }^{8}$ James S. Liebman and the Columbia DeLuna Project, The Wrong Carlos: Anatomy of a Wrongful Conviction (Columbia University Press, 2014).
} 
8 percent or more in cases of sexual assault. ${ }^{9}$ These estimates are much larger than criminal justice experts and professionals supposed before the "discovery of innocence" in the 1990s raised awareness of this problem in American criminal justice. ${ }^{10}$ The steep decline of capital punishment in the United States since 2000-death sentences and executions have plummeted-has several causes, including a sharp decrease in the homicide rate and improved capital defense, but one of the most important causes seems to be concern about miscarriages of justice, which has made prosecutors, judges, juries, and governors more cautious about capital punishment.

The problem of innocence is hardly the only problem afflicting America's death penalty system. As Chapter 2 described, death sentences are also imposed on defendants who are guilty but do not deserve to be executed. A study of more than 4500 death sentences imposed between 1973 and 1995 found that 68 percent were overturned on appeal because of "serious reversible error" in the original trial. When these cases were retried, 82 percent resulted in a sentence less than death, and 7 percent ended in acquittal. Findings such as these suggest that the actual practice of American capital punishment has all the consistency of a lottery. Errors in finding facts and assessing culpability are so widespread that American capital punishment must be called "a broken system." 11

The problem of wrongful convictions is serious in European countries too. In the former West Germany, for example, Dr. Karl Peters identified 1415 wrongful conviction cases between 1951 and 1964-an average of 101 wrongful convictions per year in a country that had 40 percent fewer people than Japan. The causes were much the same as those that have been identified by wrongful conviction researchers in the United States. ${ }^{12}$

\footnotetext{
${ }^{9}$ Dan Simon, In Doubt: The Psychology of the Criminal Justice Process (Harvard University Press, 2012), p. 4.

${ }^{10}$ Frank R. Baumgartner, Suzanna L. De Boef, and Amber E. Boydstun, The Decline of the Death Penalty and the Discovery of Innocence (Cambridge University Press, 2008).

${ }^{11}$ James S. Liebman, Jeffrey Fagan, and Valerie West, "A Broken System: Error Rates in Capital Cases, 1973-1995”, https://papers.ssrn.com/sol3/papers.cfm?abstract_id=232712.

${ }^{12}$ See Nose Hiroyuki, et al., Gohan no Kenkyu: Nishi Doitsu no Saishin Jirei no Bunseki (Hokkaido Daigaku Toshokankokai, 1981). Dr. Peters' study was originally published in Germany in 1974.
} 
The wheels of all criminal justice systems are turned by the same imperfect operations of human beings: memory, recognition, inference, social influence, self-interest, and so on. Criminal verdicts in Germany, the United States, Japan, and other countries can be no better than the combined result of these flawed human activities. ${ }^{13}$

Yet the risk of convicting innocent people is not equal across nations. There is variation from country to country within the European Union, and the risk of wrongful conviction in the United States is probably greater than in most countries of Western Europe because American systems of adversarial criminal justice strike a different balance between the need to obtain convictions and the need to find the truth than do inquisitorial criminal justice systems on the European continent. American criminal justice also relies on plea bargaining to dispose of more than 90 percent of all criminal cases, and errors in fact-finding may be more frequent in cases handled this way than in those that go to trial. For these reasons, wrongful convictions appear to be more frequent in the United States than in countries such as Germany, France, and Holland, even when taking into account differences in population and caseload. ${ }^{14}$

\section{Wrongful CONVICTIONS IN JAPAN}

Nobody knows how many persons have been wrongfully convicted in Japan, and even educated estimates are rare because few decent studies have been done. One recent effort to count identified 162 cases of confirmed or strongly suspected wrongful conviction between 1910 and 2010 , all of which were discovered in the postwar period, and more than half of which involved homicide. ${ }^{15}$ See Table 4.1 . In this century-long

${ }^{13}$ Dan Simon, In Doubt: The Psychology of the Criminal Justice Process (Harvard University Press, 2012).

${ }^{14}$ On wrongful convictions in comparative perspective, see the studies in these two books: C. Ronald Huff and Martin Killias, editors, Wrongful Conviction: International Perspectives on Miscarriages of Justice (Temple University Press, 2008); and C. Ronald Huff and Martin Killias, editors, Wrongful Convictions and Miscarriages of Justice: Causes and Remedies in North American and European Criminal Justice Systems (Routledge, 2013).

${ }^{15}$ Makoto Ibusuki and Nichibenren Enzai Gen'in Kyumei Daisansha Kikan Wakingu Gurupu, editors, Enzai Gen'in o Chosa Seyo: Kokkai ni Daisansha Kikan no Setchi o (Keiso Shobo, 2012), pp. 155-168. 
Table 4.1 Wrongful convictions in Japan by decade, 1910-2010

\begin{tabular}{lc}
\hline Decade & Number \\
\hline $1910 \mathrm{~s}$ & 2 \\
$1920 \mathrm{~s}$ & 1 \\
$1930 \mathrm{~s}$ & 0 \\
$1940 \mathrm{~s}$ & 13 \\
$1950 \mathrm{~s}$ & 37 \\
$1960 \mathrm{~s}$ & 14 \\
$1970 \mathrm{~s}$ & 31 \\
$1980 \mathrm{~s}$ & 31 \\
$1990 \mathrm{~s}$ & 16 \\
$2000 \mathrm{~s}$ & 17 \\
Total, 1910-2010 & 162 \\
\hline
\end{tabular}

Source Makoto Ibusuki and Nichibenren Enzai Gen'in Kyumei Daisansha Kikan Wakingu Gurupu, editors, Enzai Gen'in o Chosa Seyo: Kokkai ni Daisansha Kikan no Setchi o (Keiso Shobo, 2012), pp. 155-168

survey, the average number of wrongful convictions per decade is 16 , with a high of 37 in the 1950s and lows of 2 or fewer in the 1910s, the 1920 s, and the 1930s. But of course, 162 wrongful convictions in one century is surely a major undercount. In my view, this number probably represents the "tip of an iceberg" of wrongful convictions in Japan, for three reasons: because old wrongful conviction cases are difficult to document (the prewar totals are implausibly low); because less serious crimes (such as drug offenses) fell outside the scope of this study; and most fundamentally, because many cases of wrongful conviction are never discovered at all. We therefore need to ask: how big is the rest of Japan's iceberg?

Since 1945, only ten persons have been sentenced to death or life imprisonment in Japan and subsequently acquitted at retrial. Hakamada Iwao could become number eleven, if he receives a retrial (prosecutors are resisting) and if he does not die before a retrial is completed. This is an average of one exoneration every seven years - a small fraction of the frequency in the United States. The tiny number allows two contrasting interpretations. ${ }^{16}$

${ }^{16}$ David T. Johnson, "Wrongful Convictions and the Culture of Denial in Japanese Criminal Justice", The Asia-Pacific Journal/Japan Focus, Vol. 13 (2015), pp. 3-4. 
On the one hand, Japanese prosecutors tend to be cautious about charging cases. In fact, a conservative charging policy-to avoid taking defendants to trial who could be acquitted-is one of the main reasons for the country's high conviction rate. This charging policy is enforced through organizational mechanisms such as a kessai system of hierarchical consultation and review, whereby front-line prosecutors consult with their superiors about the propriety of their charge and sentence-request decisions, and a tendency to punish prosecutors who charge or try cases that end in acquittal-especially if their decision-making was deemed defective. ${ }^{17}$ On this view, Japan produces relatively few wrongful convictions because prosecutors send fewer innocent persons to trial than do their counterparts in the United States and other countries with higher acquittal rates.

The second explanation for the low number of wrongful convictions revealed in Japan stresses their discovery, not their production. On this view, Japan has relatively few actors or institutions that focus on finding wrongful convictions, and hence few are found. Japan has relatively few lawyers, only a handful of whom concentrate on criminal defense. The major national newspapers do little investigative reporting (contrast Yomiuri and Asabi with The New York Times or The Guardian). Few Japanese scholars seriously study the subject of wrongful conviction. Japan's appellate courts tend to defer to law enforcement interests and ratify the status quo. ${ }^{18}$ Japan has no exoneration registries and only established its first Innocence Project in 2016 (at Ritsumeikan University in Kyoto). And Japan has no case review commissions, except for the Japan Federation of Bar Association's Committee for the Protection of Human Rights, which has done good work in some cases, and which has published two reports (in 1998 and 2009), but which is not capable of providing assistance to all of the victims of wrongful conviction in the world's eleventh most populous country.

In sum, the number of wrongful convictions revealed in a country depends on how many have been produced and on how effectively

${ }^{17}$ David T. Johnson, The Japanese Way of Justice: Prosecuting Crime in Japan (Oxford University Press, 2002), pp. 237-242.

${ }^{18}$ Daniel H. Foote, "Policymaking by the Japanese Judiciary in the Criminal Justice Field", Hoshakaigaku, No. 72, pp. 6-45. 
they have been found. Japan's institutional shortcomings suggest that its wrongful conviction problem is larger than it appears. When Kitani Akira was a judge in Japan, he sometimes acquitted two or three defendants a year-and he acquitted about 30 defendants throughout the course of his career. Not a single acquittal was overturned on appeal. ${ }^{19}$ Is it plausible that hundreds of other Japanese judges can go year after year without issuing an acquittal - and without wrongfully convicting a single defendant? Surveys of Japanese lawyers in 1989 and 1999 suggest the answer is no, for in each of those years more than 40 percent of respondents said they had handled cases in which a wrongful conviction occurred. ${ }^{20}$ Similarly, Takano Takashi (a prominent defense lawyer) believes Japan's true total of wrongful convictions is much larger than the small number that has been officially recognized. On his analysis, Japan may produce as many as $\mathbf{1 5 0 0}$ wrongful convictions (enzai) each year, almost none of which is officially recognized. ${ }^{21}$ In the years since Takano made this estimate, Japan's acquittal rate has not significantly changed, though prosecutors have become more cautious about charging cases in the lay judge system that took effect in 2009 , as will be described in the next chapter.

\section{Structural ReForms}

Compared to the United States, Japan has not discovered many wrongful convictions, but in recent years a small stream of wrongful convictions has surfaced, including Sugaya Toshikazu, Yanagihara Hiroshi, Govinda Mainali, Sakurai Shoji, Sugiyama Takao, Boku Tatsuhiro, and Aoki Keiko. To some observers, these cases suggest that Japan is where the United States was 25 years ago-just waking up to the problem of "actual innocence" in its criminal justice system. ${ }^{22}$ Whether Japan experiences its own

\footnotetext{
${ }^{19}$ Kitani Akira, "Muzai" o Minuku: Saibankan Kitani Akira no Ikikata (Iwanami Shoten, 2013), p. 247.

${ }^{20}$ Japan Federation of Bar Associations, "Atarashii Seiki no Keiji Tetsuzuki o Motomete" (JFBA, 1999), p. 506.

${ }^{21}$ Takano Takashi, "Jijitsu Nintei wa Shimin ni Makaseta Hoga Yoi”, Keiji Saiban o Kangaeru blog, January 7, 2007, and "Nihon no Kensatsu wa Hetare na no ka", Keiji Saiban o Kangaeru blog, June 14 and June 23, 2009.

${ }^{22}$ See the Japan Innocence and Death Penalty Information Center http://www.jiadep. org/About_JIADEP.html, which is managed by Hyogo University Professor Michael H. Fox.
} 
"innocence revolution" will depend on what reforms occur in the years to come. ${ }^{23}$ In thinking about the future, it is important to remember the past. In the 1980s, four men-Menda Sakae, Taniguchi Shigeyoshi, Saito Sachio, and Akabori Masao-were released from death row because of evidence of their innocence. Afterward, many proposals were made for reform of Japan's criminal justice system, but in all fundamental respects the system remained unchanged. ${ }^{24}$ A 229-page report by the Supreme Prosecutors Office did not even acknowledge that prosecutors were wrong to indict these defendants. In the aftermath of more recent miscarriages of justice, Japan's penchant for conservative reform has been on display once again. ${ }^{25}$ In 2010, for example, who expected that the revelation of serious prosecutorial misconduct in the case of Muraki Atsuko, a senior official in the health ministry who was framed by prosecutors in Osaka and subsequently acquitted, would lead to expanded powers for prosecutors to plea bargain, wiretap, and grant immunity? Yet that is what happened in 2016, when Japan's Code of Criminal Procedure was revised to further enable these practices. In Japanese criminal justice, the more things change, the more they stay the same. ${ }^{26}$

Wrongful convictions are often caused by conformity to standard operating procedures. In many respects, the problem is systems, not devils. ${ }^{27}$ Hence, addressing the problem of wrongful convictions requires systemic and structural reforms. For starters, Japan needs to develop better institutions for finding wrongful convictions after they occur. In this respect, Japan remains well behind the United States and England. The study of wrongful convictions also needs to become more important in Japan's legal academy. For this to happen, funders must make the subject a higher research priority.

${ }^{23}$ Harada Kunio, Gyakuten Muzai no Jijitsu Nintei (Keizo Shobo, 2012).

${ }^{24}$ Daniel H. Foote, "From Japan's Death Row to Freedom”, Pacific Rim Law \& Policy Journal, Vol. 1, No. 1 (1992), p. 102; and Daniel H. Foote, "The Door That Never Opens: Capital Punishment and Post-conviction Review of Death Sentences in the United States and Japan”, Brooklyn Journal of International Law, Vol. 19, No. 2 (1993), pp. 367-521.

${ }^{25}$ Suo Masayuki, Sore demo Boku wa Kaigi de Tatakau: Dokyumento Keiji Shiho Kaikaku (Iwanami, 2015).

${ }^{26}$ As Giuseppe Tomasi di Lampudesa has the Prince's nephew say in The Leopard, "If we want things to stay as they are, things will have to change" (London: Fontana, 1963), p. 27.

${ }^{27}$ James M. Doyle, "The Real Culprits in the Central Park 5 Convictions", The Crime Report, July 8, 2019. 
Wrongful convictions must also be prevented before they occur. To do so, Japan should implement internationally recognized "best practices" in its criminal justice system, the most important of which is a requirement to electronically record all criminal interrogations in their entirety. Japan has made progress in this direction, but much more needs to be done. The 2016 revision to the Code of Criminal Procedure made it mandatory for police and prosecutors to video record interrogation in cases that will be handled by lay judge trials and in cases that are independently initiated by prosecutors, but these account for only 2 to 3 percent of all criminal cases in the country. The new law also allows investigators to forego recording if they believe recording will inhibit suspects from making meaningful statements, and it imposes no obligation to record statements made by people being questioned on a voluntary basis either prior to arrest or after indictment. These loopholes are so large that they could swallow the principle of transparency to which they are supposed to be exceptions.

When a wrongful conviction occurs in Japan, a false confession is usually the primary proximate cause. One study found that "a confession was part of the evidence marshaled against defendants in 84 percent (42 out of 50) of the confirmed enzai cases between 1945 and 1991 in which a conviction was later overturned." 28 This is a much higher percentage than in American exonerations. False confessions were also centrally relevant in all four of the Japanese death penalty cases that ended in retrial and acquittal in the 1980s, and in Hakamada's half-century nightmare as well. Yet in the Special Committee on Criminal Justice for a New Era (Shinjidai no Keiji Shiho Seido Tokubetsubukai), which ostensibly aimed to address some of the problems exposed by the aforementioned prosecutorial scandal, "sweet-talking for the government" by prominent Japanese professors resulted in remarkably lax recommendations for reform-reform that could have created substantially more transparency and accountability in Japan's interrogation rooms. But instead,

\footnotetext{
${ }^{28}$ John H. Davis, “Courting Justice, Contesting 'Bureaucratic Informality': The Sayama Case and the Evolution of Buraku Liberation Politics", in Patricia G. Steinhoff, editor, Going to Court to Change Japan: Social Movements and the Law in Contemporary Japan (Center for Japanese Studies at the University of Michigan, 2014), p. 76.
} 
interrogation rooms remain some of the most closed and secretive spaces in Japanese society. ${ }^{29}$

There are many good reasons to record interrogations, and no good reasons not to. Compared to other democracies, this need is especially great in Japan, where interrogations are long and the suspect's right to silence is undermined by a "duty to endure questioning." 30 Because electronic recording is a medium for preserving the truth of interrogations and confessions, it serves what is widely regarded as the cardinal objective of Japanese criminal justice: truth-finding. Recording also serves the interests of all the parties in the criminal process. Defendants and defense attorneys benefit because recording deters impermissible interrogation techniques and helps prevent wrongful convictions based on false confessions. Police and prosecutors benefit because recording protects them against false accusations of impropriety and abuse. And judges and lay judges benefit because recording gives them the information they need to assess the voluntariness and veracity of confessions.

Prosecutors must also become more transparent about the evidence in their possession, and Japanese history suggests they will not do so voluntarily. Since the "Conspiracy at Matsukawa" case ${ }^{31}$ that resulted in the wrongful conviction of 20 men in 1950 and their subsequent acquittal, it appears that every exoneration in Japan has been preceded by the failure of prosecutors to disclose critical evidence to the defense. In Hakamada's case, that failure endured for decades. In this respect, Japan's procuracy may be less transparent today than it was before the Occupation, when prosecutors were required to disclose all dossiers to the defense, not just the statements they submitted as evidence at trial. ${ }^{32}$

The evidence in a criminal case is not owned by the state. It is a public good, and state officials should be required to share it with the

\footnotetext{
${ }^{29}$ Suo Masayuki, Sore demo Boku wa Kaigi de Tatakau: Dokyumento Keiji Shibo Kaikaku (Iwanami, 2015).

${ }^{30}$ On criminal interrogation in Japan, see Setsuo Miyazawa, Policing in Japan: A Study on Making Crime (State University of New York Press, 1992); and Daniel H. Foote, "Confessions and the Right to Silence in Japan", Georgia Journal of International and Comparative Law, Vol. 21 (1991), pp. 415-488. On criminal interrogation in the United States, see Richard A. Leo, Police Interrogation and American Justice (Harvard University Press, 2008).

${ }^{31}$ Chalmers Johnson, Conspiracy at Matsukawa (University of California Press, 1972).

${ }^{32}$ David T. Johnson, The Japanese Way of Justice: Prosecuting Crime in Japan (Oxford University Press, 2002), p. 272.
} 
defense. ${ }^{33}$ But prosecutors in Japan have worked hard to delimit the defense's rights to discovery, and its justifications have been self-serving. For an organization that trumpets the importance of truth-telling so much, it is ironic that the procuracy opposes disclosing to the defense more of the building blocks-draft dossiers especially-that front-line prosecutors use to construct "the truth" they advocate at trial. ${ }^{34}$ The present system also relies inordinately on the goodwill of prosecutors to disclose relevant evidence to the defense, though occasionally they are spurred to do so by "recommendations" from the bench. In Shizuoka, repeated nudges by judges led to the belated disclosure of evidence to Hakamada's defense lawyers and ultimately to release of the world's longest incarcerated inmate on death row. To prevent more miscarriages of that kind, prosecutors should be required to disclose all of the evidence in their possession to the defense before a trial starts. In some parts of the United States and in other jurisdictions, this is called "full file disclosure."

As described in Chapter 2, Japanese legal professionals-prosecutors, judges, and defense lawyers-frequently emphasize the need to be "cautious" (shincho) about capital punishment. But if Ministers of Justice and prosecutors were serious about this assertion, they would seek reforms that recognize how justice can miscarry. Recording interrogations in their entirety and disclosing all evidence to the defense would reduce the risk of wrongful conviction in Japanese criminal justice. Until these reforms are realized, claims about the need to be "cautious" will sound like empty rhetoric.

\section{A Culture of Denial}

The structural reforms described above are essential, but without a change in Japan's culture of criminal justice they will have limited impact. Reforming institutions is the main means of change in the modern approach to developing democracy, but the notion that structural

\footnotetext{
${ }^{33}$ Makoto Ibusuki, “Subete no Shoko Kaiji o Isoge: Hakamada Jiken no Kyokun”, Asahi Shimbun, May 9, 2014.

${ }^{34}$ David T. Johnson, The Japanese Way of Justice: Prosecuting Crime in Japan (Oxford University Press, 2002), pp. 98-99.
} 
reform alters actual practice is more hope than fact. ${ }^{35}$ Research on "making democracy work" warns that the "designers of new institutions are often writing on water." 36 That is, culture and history strongly condition the effectiveness of new rules and institutions, and long-established norms can limit the possibilities for achieving structural reform. Because culture counts, addressing the problem of wrongful convictions must attend to this area too. The most important imperative concerns cultural assumptions that are relevant in many areas of Japanese society, from aviation and medicine to nuclear energy and criminal justice. Three principles are primary. ${ }^{37}$

First, in order to reduce error one must assume it is inevitable. When I started studying criminal justice in Japan in the early 1990s, prosecutors told me that the miscarriages of justice that happened in the first decade or so after the Pacific War "could not occur anymore" because they were caused by an immature system of criminal justice that had been radically reformed during the Occupation and that was still working out its problems in the early postwar period. Subsequent events revealed that claim to be false. Japan continues to have problems with wrongful conviction, and the most serious problem involves a culture of denial that makes it difficult for police, prosecutors, and judges to acknowledge their own mistakes and for the media and other external agents of accountability to conduct rigorous investigations. ${ }^{38}$ Because this culture of denial shields those actors from pain, humiliation, and change, it is easy to understand why they cling to it. Letting the culture of denial go and embracing the lessons that error can teach will require honor and courage. It also will require pressure from Japanese society - and from political leaders especially. Culture, not politics, often determines the success of legal reforms, though politics can change a culture and save it from itself. ${ }^{39}$

\footnotetext{
${ }^{35}$ Bent Flyvbjerg, Rationality and Power: Democracy in Practice (University of Chicago Press, 1998).

${ }^{36}$ Robert Putnam, Making Democracy Work: Civic Traditions in Modern Italy (Princeton University Press, 1993), p. 17.

${ }^{37}$ For more details, see Kathryn Schulz's brilliant book Being Wrong: Adventures in the Margin of Error (Ecco, 2010), pp. 304-307.

${ }^{38}$ Hiromasa Ezoe, Where Is the Justice? Media Attacks, Prosecutorial Abuse, and My 13 Years in Japanese Court (Kodansha, 2010).

${ }^{39}$ Lawrence E. Harrison, The Central Liberal Truth: How Politics Can Change a Culture and Save It From Itself (Oxford University Press, 2006).
} 
Second, in fields like medicine and aviation, successful strategies for error prevention rely on principles of openness and transparency to identify and learn from mistakes. ${ }^{40}$ In contrast, Japan's system of criminal justice is so hostile to outside scrutiny that it remains impossible to see or say what many of its problems are. Most interrogations are not electronically recorded. It is all but impossible to do field research on policing. Prosecutors possess broad discretion to withhold evidence from the defense, and they are not reluctant to hide evidence when it serves their own interests. Lay judges are not permitted to discuss case details or deliberations even after their service has ended. And Japan's system for administering executions is surrounded by secrecy that is taken to extremes not seen in other nations. The insularity of Japanese criminal justice reflects the mistaken assumption that criminal proceedings are the special province of legal professionals. Whether Japan experiences its own "innocence revolution" depends partly on how transparent its criminal justice system becomes. At present, there may be no democratic country in the world where criminal justice is more closed.

The third cultural principle of error prevention is reliance on data so that criminal justice can be administered based on facts rather than on opinions, assumptions, and the prerogatives of power. But since empirical criminology is not well developed in Japan, little is known about how Japanese criminal justice is patterned. One key cause of this ignorance is the resistance of Japanese criminal justice officials to being studied in a serious way. Some Japanese scholars have experienced this resistance firsthand-and so have I. Several years ago I went to Tokyo to do research about policing in Kabukicho in the Shinjuku district. I was relying on the promise of an executive in the National Police Agency, that I would be given meaningful access to study police patrol activity in Japan's largest red light district. Despite several months of my best efforts, the promised access never materialized. I was given plenty of official police publications, and lots of bows and handshakes, but when I was permitted to do any field research at all, it consisted of standing outside police boxes (koban) in safe suburban settings such as Fuchu, far removed from the action I was interested in. And all the while I was in the "field,"

${ }^{40}$ James M. Doyle, "Learning from Error in the Criminal Justice System: Sentinel Event Reviews", in National Institute of Justice, Mending Justice: Sentinel Event Reviews (U.S. Department of Justice, September 2014), pp. 3-18. 
I was watched by police-handlers from the Tokyo Metropolitan Police Department, who seemed as bored with their assignment to manage this foreigner as I was with my own meager access to their world.

Police are the most understudied actors in Japanese criminal justice. ${ }^{41}$ This is ironic and unfortunate, for they are also the most important actors in Japan's criminal process. That criminal process is only as good as the evidence on which it feeds, and it is Japanese police who collect most of the evidence which informs criminal justice decision-making. Yet in Japan, hardly anyone studies police in a serious way. As one Japanese journalist observed:

If a prominent sociologist from the West...came here to research the Japanese police, that scholar undoubtedly would conclude that this country is 'a strange land.' First he would run into the police wall of secrecy, and he would be unable to investigate actual police practices and conditions. Next he would be informed that there is no investigative reporting about the police by newspaper or other mainstream journalists, and that there are very few free-lance journalists who follow police issues. Then he would learn that in Japanese colleges and universities there are no courses about the police (as there are in the West) and no scholars who seriously study them. In the end, our friend the sociologist would discover that citizens and taxpayers (who have entrusted their safety to the police) have an extremely weak consciousness to try to check the police. Such a scholar, I think, would be seized by this question: Is Japan really a democratic country? ${ }^{42}$

Two decades after this passage was published, Japan remains a "strange land" with respect to research on police. Without decent data about them, reporters, citizens, and elected officials will remain easily manipulated by the public relations efforts of Japan's most powerful government agency.

\section{Toxic TO JUstice}

Wrongful convictions are inevitable in all criminal justice systems, but they can be significantly curtailed. In the United States, police or prosecutors initiate or cooperate in more than half of all exonerations, and

${ }^{41}$ David T. Johnson, "Policing in Japan", in James D. Babb, editor, The Sage Handbook of Modern Japanese Studies (Sage, 2015), pp. 222-243.

${ }^{42}$ M. Kobayashi, Nihon Keisatsu no Genzai (Iwanami Shoten, 1998), p. vi. 
about 30 prosecutors' offices across the country have created "conviction integrity units" (CIUs) to review wrongful conviction claims. ${ }^{43}$ Of the 166 exonerations that occurred in America in 2016, 70 came from CIUs. One of the first CIUs was created in Dallas in 2007 under Craig Watkins, an African-American District Attorney who grew concerned about the alarming number of miscarriages of justice that had been revealed in his jurisdiction. Since then, more than 90 percent of CIU exonerations have occurred in four large counties: Harris (Houston, Texas), Dallas (Texas), Cook (Chicago, Illinois), and Kings (Brooklyn, New York). The concentration of exonerations in a few CIUs suggests that some CIUs are more effective than others at uncovering wrongful convictions. One of the best models is in Brooklyn, where 10 full-time prosecutors work on more than 100 cases at any given time. As of the end of 2017, 23 people had been exonerated in Brooklyn, and of the cases reviewed there, 50 involved the bad behavior of a single retired detective named Louis Scarcella, who put away innocent people on false charges, over decades, by whatever means necessary-forced confessions, witness tampering, and a callous disregard for fairness and justice. ${ }^{44}$

The more open orientation to mistakes now seen in American CIUs is a marked break from the culture of denial that long characterized prosecution in the United States, and it also helps explain why there have been so many more exonerations in America than in Japan. America still has a long way to go to adequately address its problem with wrongful convictions, but the increased willingness to acknowledge error and learn from mistakes must be reckoned one of the most welcome developments in the past half-century of American criminal justice. By contrast, exonerations in Japan are almost always achieved despite strong resistance from police and prosecutors, and Japanese judges are frequently slow to acknowledge error as well (while Hakamada Iwao was detained on death row, more than a dozen judges rejected his appeals). If prosecutors in Japan are really the champions of justice that they claim to be, shouldn't they be creating CIU-like institutions that proactively search for errors?

\footnotetext{
${ }^{43}$ See "Conviction Integrity Units", at the National Registry of Exonerations webpage, https://www.law.umich.edu/special/exoneration/Pages/Conviction-Integrity-Units.aspx.

${ }^{44}$ For more on recent changes in American prosecution, see Emily Bazelon, Charged: The New Movement to Transform American Prosecution and End Mass Incarceration (Random House, 2019).
} 
It is often said that "to err is human," but once a mistake has been made, humans have a choice between "covering up" and "fessing up." In June 2018, the Tokyo High Court overturned the ruling that had released Hakamada from death row because of evidence of his innocence, though the octogenarian was allowed to retain his freedom until the case returns to the Supreme Court. The next month, Japanese prosecutors exhorted the Supreme Court to reject Hakamada's appeal and to "stop this situation in which his sentence of death is suspended unnecessarily." Prosecutors' position appears to have two main causes: a desire to protect their individual and collective reputations, and a tendency toward tunnel vision, which leads them to dismiss evidence that is inconsistent with their preferred outcome ("guilty!") as irrelevant, incredible, or unreliable.

A path-breaking study of what it means to "be wrong" points out that if you recognize that errors are inevitable, you will not be surprised when they occur and you will have plans in place to correct them. ${ }^{45}$ Conversely, if you refuse to admit that mistakes do occur, then every mistake-and every revelation of a wrongful conviction-becomes stark and humiliating evidence of how wrong you are. In this sense, Japan's culture of denial is toxic to justice, and so is the self-righteous certainty of criminal justice officials concerning the propriety of their own conduct. Doubt is a skill they still need to learn, and error is a reality they must learn to acknowledge. But they will not learn these lessons on their own. How long will Japanese society tolerate the status quo? And when will this country take an interest in the iceberg?

\footnotetext{
${ }^{45}$ Kathryn Schulz, Being Wrong: Adventures in the Margin of Error (Ecco, 2010), especially Chapter 14 on "The Paradox of Error".
} 
Open Access This chapter is licensed under the terms of the Creative Commons Attribution-NonCommercial-NoDerivatives 4.0 International License (http://creativecommons.org/licenses/by-nc-nd/4.0/), which permits any noncommercial use, sharing, distribution and reproduction in any medium or format, as long as you give appropriate credit to the original author(s) and the source, provide a link to the Creative Commons license and indicate if you modified the licensed material. You do not have permission under this license to share adapted material derived from this chapter or parts of it.

The images or other third party material in this chapter are included in the chapter's Creative Commons license, unless indicated otherwise in a credit line to the material. If material is not included in the chapter's Creative Commons license and your intended use is not permitted by statutory regulation or exceeds the permitted use, you will need to obtain permission directly from the copyright holder.

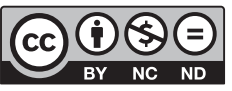

